\title{
Review
}

Journal of Innate

Immunity
J Innate Immun 2017;9:3-11

DOI: $10.1159 / 000451026$
Received: August 8, 2016

Accepted after revision: September 26, 2016

Published online: October 29, 2016

\section{Non-Pulmonary Immune Functions of Surfactant Proteins A and D}

\author{
Sylvia Ujma ${ }^{a-c}$ William G.C. Horsnell ${ }^{b, d}$ Arieh A. Katz ${ }^{a-c}$ Howard W. Clark $^{\mathrm{e}}$ \\ Georgia Schäfer ${ }^{a-c}$ \\ a UCT Receptor Biology Research Unit, Division of Medical Biochemistry and Structural Biology, Department of \\ Integrative Biomedical Sciences, b Institute of Infectious Disease and Molecular Medicine, 'SAMRC Gynecology \\ Cancer Research Centre, and dDivision of Immunology, Department of Pathology, Faculty of Health Sciences, \\ University of Cape Town, Cape Town, South Africa; ${ }^{e}$ Child Health, Division of Clinical and Experimental Sciences, \\ Department of Child Health, University of Southampton, Southampton, UK
}

\section{Key Words}

Surfactant protein A - Surfactant protein D - Female reproductive tract . Urinary tract - Gastrointestinal tract

\begin{abstract}
Surfactant proteins A (SP-A) and D (SP-D) are established as essential components of our innate immune system for protecting the lung from pathogens and allergens. They essentially exert their protective functions by regulating pulmonary homeostasis. Both proteins are however widely expressed throughout the body, including the female reproductive tract, urinary tract, gastrointestinal tract, the eye, ear, nasal compartment, central nervous system, the coronary artery and the skin. The functions of SP-A and SP-D at these sites are a relatively underinvestigated area, but it is emerging that both SP-A and SP-D contribute significantly to the regulation of inflammation and protection from infection at these sites. This review presents our current understanding of the roles of SP-A and SP-D in non-pulmonary sites.

(c) 2016 S. Karger AG, Basel
\end{abstract}

\section{Introduction}

Surfactant proteins A and D (SP-A and SP-D, respectively) are large, collagenous, hydrophilic proteins which belong to a family of proteins known as the collectins. They were first identified in pulmonary surfactant, a phospholipid and protein complex that lines the lungs and is essential for pulmonary function by reducing surface tension [1]. Moreover, the interaction of SP-A and SP-D with airborne pathogens revealed their central role in host defence in the lung [2].

The primary structure of both SPs consists of an Nterminal non-collagenous domain capable of forming intersubunit disulphide bonds, a collagenous region of Gly$\mathrm{X}-\mathrm{Y}$ repeats, a helical neck domain and a globular C-terminal carbohydrate recognition domain (CRD), each one with different ligand-binding specificities. Monomers spontaneously self-assemble into trimers which then form the higher-order bunch-like SP-A octadecamers, and the cruciform SP-D dodecamers, respectively [3]. Although structurally very similar, SP-A and SP-D display distinct activities and modes of action which is reflected by their different ligand-binding affinities: SP-A prefer-

\section{KARGER}

(c) 2016 S. Karger AG, Basel

E-Mail karger@karger.com

www.karger.com/jin
Dr. Georgia Schäfer

Institute of Infectious Disease and Molecular Medicine (IDM), Division of Medical Biochemistry, University of Cape Town, Wernher and Beit Building North, Room N2.02 Anzio Road, Observatory 7925, Cape Town (South Africa)

E-Mail georgia.schafer@uct.ac.za 
entially binds to monosaccharides and lipid ligands, while SP-D additionally binds disaccharides, complex carbohydrates and anionic phospholipids present on cell surfaces [4]. This might be explained by subtle structural differences between the CRDs of trimeric SP-A and SP-D resulting in the flatter and more hydrophobic surface of SP-A preferentially binding to less polar substrates, while the more hydrophilic surface of SP-D displays a higher affinity for highly polar targets $[5,6]$. Moreover, in SP-A, the Gly-X-Y repeats in the collagenous region are interrupted resulting in a kink (and hence the bunch-like structure) and a relatively smaller distance to the distal CRD compared to SP-D which displays more freedom to bind and aggregate target pathogens [3].

SP-A and SP-D play important roles in innate immune responses to a wide range of respiratory pathogens including influenza A virus, respiratory syncytial virus, $M y$ cobacterium tuberculosis, Aspergillus fumigatus, Pseudomonas aeruginosa and Haemophilus influenzae [7-14]. Additionally, it has recently been shown that pulmonary SP-D contributes significantly to host control of infections by the parasitic helminth Nippostrongylus brasiliensis [15]. Recognition and binding of this diverse variety of incoming pathogens by SP-A and SP-D trigger various immune responses, including opsonisation leading to enhanced phagocytosis and killing by recruited macrophages and neutrophils via oxidative mechanisms, aggregation of pathogens thereby hindering their entry into host cells, and direct microbicidal activities by increasing cellular membrane permeability (reviewed in [2]). SPs also assist in the clearance of apoptotic cells and in modulating inflammation $[2,16]$. The interaction of SPs with immune cells to initiate clearance mechanisms is mediated by SP's collagen region with a number of proposed receptor molecules on these cells [3]. (For a detailed review of SP functions and mechanism in clearance of pathogens in the lung, please refer to Kishore et al. [3]).

SP-A and SP-D are also important for maintaining immune homeostasis in the lung by either enhancing or suppressing the production of inflammatory molecules by, for example, alveolar macrophages [17]. SP-A and SP-D mediate this protection in part at least via CRD binding to signal inhibitory regulatory protein $\alpha$ (or CD172a), and this interaction can maintain macrophages in a homeostatic state [17]. The significance of SP-D in maintaining lung homeostasis is particularly well demonstrated by pulmonary pathological phenotypes in SP-D-deficient mice; these display substantial abnormalities in surfactant homeostasis and alveolar cell morphology and spontaneously develop chronic inflammation and emphyse- ma-like pathology [18]. This observation also supports the perceived stronger potency of SP-D compared to SPA: the absence of SP-A does not result in significant physiological effects in mice [19]. The significance of these preclinical findings is also supported by clinical studies which have shown that individuals with reduced or altered SP-D present with severer chronic obstructive pulmonary diseases or asthma [20].

SP-A and SP-D functions are therefore important in both maintaining lung homeostasis and protecting this site from infection. However, SP-A and SP-D are also widely expressed at other mucosal surfaces throughout the body, but their contribution to host immunity and immune homeostasis at these sites is not as well understood. In this review, we will give a short overview of our current understanding of the non-pulmonary locations of SP-A and SP-D and their proposed functions in these regions, and identify key areas where understanding their function may be of biomedical importance.

\section{The Female Reproductive Tract}

SP-A and SP-D have been detected throughout the female reproductive tract by immunohistochemistry and RT-PCR. In humans, SP-A has been found in the myometrium, vaginal epithelial tissue as well as vaginal lavage fluid, and SP-D has been detected in the epithelial layers of the vagina, cervix, endometrium, fallopian tubes and ovaries [21-23]. By sampling at different times of the menstrual cycle, it was shown that levels of SP-A vary in vaginal lavage fluid: peak levels are observed during the follicular phase, which may be beneficial as in the postmenses period the vagina is more susceptible to infection due to the vaginal mucosa being thinned with unstable vaginal flora [24]. SP-D levels in the endometrium also vary according to the menstrual cycle, as here SP-D levels peak in the secretory phase [23]. In the murine reproductive tract, SP expression is most prominent in the oviduct, with lower expression observed in the uterus, cervix and vagina. Expression of SP-D in the murine uterus is highest during oestrus, and it is speculated that SP-D expression may here be regulated by oestrogen, which peaks late in pro-oestrus. The increase in SP-D during oestrus may also be linked to the increased neutrophilia associated with di-oestrus, with SP-D potentially functioning as a chemoattractant [25].

SP-A and SP-D expression in the female reproductive tract has naturally been suggested to contribute to innate immune protection against sexually transmitted infections 
$[22,23]$, and evidence exists to support this. In vitro, SP-D can inhibit infection of the human cervical epithelial cell line HeLa by Chlamydia trachomatis [26]. In vivo, murine infections with Chlamydia muridarum have been shown to enhance SP-D expression in the cervix, supporting a role for SP-D in defence against Chlamydia infections [25]. SP-A and SP-D also interact with human immunodeficiency virus (HIV). The glycosylated HIV envelope protein gp120 can be bound by both SP-A and SP-D to potentially inhibit HIV infectivity of CD4 T cells [27, 28]. SP-A and SP-D also enhance HIV uptake by dendritic cells, which may be an unfavourable interaction in terms of host immunity against $\mathrm{HIV}$, as dendritic cells transfer the virus to CD4 T cells $[27,28]$. It therefore seems that SP-A and SP-D inhibit direct infection as well as enhance indirect infection of CD 4 cells by HIV, showing that they may have contrasting effects with regard to immunity against HIV.

As mentioned above, SP-D levels are increased in the endometrium in the secretory stage of menstruation, which may help prevent intrauterine infections [23]. This is especially important in ensuring successful pregnancies, as these infections can lead to complications of pregnancy such as premature birth, still birth and neonatal sepsis [29]. In pregnancy, SP-A and SP-D are present in the amniotic fluid, placenta, amnion and chorion $[23,30]$. The potential protective role of these proteins in pregnancy has been described by several studies. Expression of SP-A and SP-D is elevated in the first trimester decidua (maternal part of the placenta) by trophoblasts and decidual stromal cells [31]. The potential function of this increase in SP-A and SP-D in protection from bacterial infection is supported by the SP-A- and SP-D-mediated reduction of lipopolysaccharide (LPS)-induced inflammation associated with TNF- $\alpha$ release by decidual macrophages [29]. At term, SP-A has been shown to decrease in the amniotic fluid, possibly due to it being sequestered by receptors in the amnion [32]. Additionally, amnion explants treated with SP-A exhibit decreased IL-1 $\beta$, CXCL2, and CXCL5 mRNA expression. It has therefore been suggested that SP-A in the amniotic fluid protects the amnion and amniotic cavity from inflammation, thus protecting the foetus [32]. SP-A1 mRNA is significantly upregulated in the foetal membranes of patients who experience preterm birth with chorioamnionitis (as compared to preterm birth without chorioamnionitis), suggesting that SP-A may be involved in regulating inflammation in this compartment [33]. Furthermore, a genetic polymorphism in the SP-D gene (Met31Thr, which has previously been linked to influence serum concentrations and oligomerisation of SP-D) has been associated with

Non-Pulmonary Functions of SP-A and SP-D preterm birth [34]. Taken together, these findings suggest that SP-A and SP-D have a potential role in protecting the foetus during pregnancy and preventing preterm birth.

Some studies have implicated SP-A production in the onset of labour: in mice, increased production of SP-A by the foetal lung towards the end of term was shown to drive the activation of amniotic fluid macrophages as well as their migration to the uterus, resulting in an increased production of IL- $1 \beta$ and NF- $\kappa B$ which contributes to the initiation of labour [35]. Additionally, injection of SP-A into the amniotic fluid has been shown to both cause and prevent preterm birth [35, 36]. As mentioned above, SP-A has been shown to have an anti-inflammatory effect on amnion explants, further contradicting the role of SP-A in the onset of labour. These contrasting results may be explained by species-specific differences of SP functions in the various reproductive compartments [3].

\section{The Urinary Tract}

Similarly to the reproductive tract, the urinary tract can be infected by external pathogens causing urinary tract infections. SP-A and SP-D have been detected by RT-PCR and immunohistochemistry in the kidney and epithelium of the ureter and bladder $[37,38]$, and they are likely to have a protective role in these regions. In vitro, SP-A and SP-D inhibit the growth of uropathogenic Escherichia coli [37], and SP-D reduces bacterial adherence to human bladder cells [39]. In vivo experiments on SP-A and SP-D double-knockout mice showed that these mice have an increased susceptibility to urinary tract infections by uropathogenic E. coli, as measured by higher bacterial loads in the kidney and urine [37]. The kidneys of wildtype mice were histologically normal after infection, whereas in the knockout mice, neutrophil and monocyte infiltrates were noted in the medulla, indicating a higher inflammatory response in these mice [37]. Additionally, mice infected with uropathogenic E. coli exhibited higher levels of SP-D mRNA in the bladder as compared to uninfected mice [39]. SP-D may also play a protective role against tubulointerstitial fibrosis (the common pathway to end-stage renal disease), as overexpressing SP-D in human kidney proximal tubular cells inhibits the expression of monocyte chemoattractant protein-1, a protein that when upregulated leads to disease progression [40]. In a study involving Chinese women, it was found that individuals carrying an Ala19Val polymorphism in SP-A1 or a Lys223Gln polymorphism in SP-A2 show increased susceptibility to recurring urinary tract infections [41], 
further emphasising that SPs seem to have important roles in preventing infection of the urinary tract.

\section{The Gastrointestinal Tract}

In the gastrointestinal tract (GIT), SP-A is expressed in the columnar epithelial cells lining the villi and crypts of the small intestine, as well as in the surface epithelial cells of the large intestine [42], while SP-D is expressed in the epithelial lining of the small intestine as well as at low levels in the large intestine and stomach [38]. However, our understanding of the role these proteins have in these compartments is surprisingly limited. Functionally, both SP-A and SP-D in the GIT appear to act both in the control of pathogens and in the regulation of immunity. In vivo experiments on the porcine GIT showed that SP-D aggregates a variety of Gram-negative bacteria, thereby enhancing the uptake of these pathogens by intestinal epithelial cells, allowing for a more rapid immune response [43]. SP-D may also contribute to the control of parasitic helminth infections based on observations that non-lung SP-D also contributes to the resolution of $N$. brasiliensis infection; however, we do not currently understand how this effect may be mediated [15].

Both SP-A and SP-D have been implicated in controlling inflammatory bowel disease and necrotising enterocolitis. In the case of inflammatory bowel disease, there is an overexpression of SP-A [44], and a single-nucleotide polymorphism of SP-D (G/A Ala160Thr) has been associated with susceptibility to Crohn's disease, one of the subtypes of inflammatory bowel disease [45]. SP-A and SP-D have also been shown to contribute to protection against necrotising enterocolitis, a disease of preterm infants which is associated with an overexpression of Toll-like receptor 4 in the intestine. For example, in vitro pretreatment of intestinal cell cultures with SP-D reduced the LPS-induced release of proinflammatory cytokine IL-8 [46], while in a rat model of necrotising enterocolitis, oral administration of SP-A reduced mortality and intestinal pathology, as well as levels of proinflammatory cytokines (IL-1 $\beta$, TNF- $\alpha$ and INF- $\gamma$ ) and Toll-like receptor 4 [47]. These studies emphasise the potential importance of SP-A and SP-D in controlling inflammation to prevent pathological states.

SP-A and SP-D are also expressed in the oral cavity of the upper GIT. They have been detected in the gingiva, saliva, as well as the parotid and submandibular glands, especially in serous acinus cells and epithelial cells lining the ducts [48]. ELISA experiments have shown that SP-A and SP-D expression is upregulated in saliva from pa- tients suffering from periodontal disease as compared to saliva from healthy patients [49]. Additionally, in chronic sialadenitis (inflammation of the salivary glands), SP-A expression is upregulated [50]. This suggests that during pathological conditions of the mouth, SP-A and SP-D are upregulated, possibly to assist in combating infection.

\section{Other Sites of SP-A and SP-D Expression}

\section{The Eye}

SP-A and SP-D have been located in various parts of the eye: the conjunctiva, superficial layers of the cornea, the lacrimal and nasolacrimal glands, as well as in tear fluid [51]. SP-D knockout mice are less efficient at clearing Staphylococcus aureus and P. aeruginosa infection from the ocular surface as compared to wild-type mice, as determined by quantifying the bacterial colony-forming units in tear fluid $[52,53]$. S. aureus-infected SP-D knockout mice also have severer ocular surface injury as compared to infected wild-type mice, and SP-D levels in wild-type mice increase after infection [53]. It has also been noted that cultured human corneal epithelial cells express higher levels of SP-D when exposed to heat-killed P. aeruginosa or A. fumigatus spores [54, 55]. Additionally, higher levels of SP-A and SP-D have been detected in corneal endothelial and epithelial cells as well as in the corneal stroma of eyes with corneal ulceration and herpetic keratitis [51]. These findings suggest that SP-A and SP-D have important roles in the innate defence of the eye, and that their production in the eye can be induced or upregulated due to infection.

\section{The Middle Ear}

By using electron and immunoelectron microscopy as well as in situ hybridisation, it was found that SP-A and SP-D are expressed in the eustachian tube epithelium as well as lavage fluid [56]. The eustachian tube links the middle ear and nasopharynx, and can potentially be infected by pathogens from the lungs, which may lead to otitis media, a middle ear inflammatory disease which most commonly occurs in children [56]. In vivo, otitis media was induced in mice by injection of LPS derived from Klebsiella pneumoniae directly to the middle ear, and it was noted that these mice had significantly increased SP-A expression in the middle ear, indicating that SP-A may be upregulated due to infection [57].

\section{The Nasal Compartment}

The innate immune components of the nasal epithelium are vital to prevent upper respiratory tract infec- 
tions. Immunohistochemistry has shown that SP-A and SP-D are expressed in the nasal epithelium, more specifically in the cytoplasm of ciliated epithelial cells and in the serous acini of the submucosal gland [58]. Additionally, both SP-A and SP-D are present in the nasal lavage fluid [59]. Their possible role in immunity in the nasal mucosa has been supported by studies showing that they are differentially expressed in individuals with certain nasal pathologies. In cystic fibrosis, SP-A1, SP-A2 and SP-D mRNA expression is significantly upregulated in the sinus mucosa [60]. Both SP-A and SP-D are more strongly expressed in the submucosal glands of patients with chronic rhinosinusitis (CRS) [59]. These increased levels of SP-A and SP-D are also seen in the nasal lavage fluid of patients with CRS without nasal polyps, but not in CRS with nasal polyps, and this is likely due to the secretion of the proteins being impaired due to severe damage of the mucosa in this case [59]. Experiments on CRS nasal tissue explants have shown that SP-D mRNA is upregulated in response to A. fumigatus and Alternaria tenuis [61]. Additionally, in patients with CRS without polyps, there is an association between colonisation of the nasal passages with pathogenic bacteria and higher levels of SP-A and SP-D in the nasal lavage fluid, indicating that SP-A and SP-D are upregulated in these cases due to infection [59].

\section{The Central Nervous System}

Recently, by using RT-PCR and Western blotting, it was determined that both SP-A and SP-D are located in the brain stem, choroid plexus, cerebellum, subventricular cortex, pia mater and cerebral spinal fluid (CSF) of the central nervous system (CNS) [62]. ELISAs were used to determine whether there is a variation in SP-A and SP-D levels in CSF depending on the state of health, and it was seen that they did indeed vary among healthy, autoimmune CNS disease and CNS infection samples (infection samples were derived from patients diagnosed with meningitis, encephalitis or meningoencephalitis). As compared to samples from healthy individuals, there was a significant decrease in SP-A and SP-D levels in the CSF of individuals with CNS autoimmune disease or CNS infection. It has been suggested that SP-A and SP-D may function by binding and removing microbes and exhausted neutrophils in the CSF, which results in decreased SPs being detected [62].

\section{Coronary Artery}

SP-D has been detected in endothelial and smooth muscle cells of the coronary arteries by immunostaining of tissue sections [63]. The possible role of SP-D in this tissue was explored using human coronary artery smooth muscle cells, whereby inflammation was stimulated by addition of LPS. During inflammation, SP-D expression was increased, and overexpression or administration of SP-D reduced the expression of IL-8, indicating that SP-D plays an important role in modulating inflammation in this tissue. Low levels of inflammation and IL-8 release have been associated with the development of atherosclerosis, and therefore, it seems that SP-D may have a role in modulating this disease. Additionally, it was observed that after infection with Chlamydia pneumoniae, there are reduced viable C. pneumoniae inclusions in the presence of SP-D [63], suggesting that SP-D may be important in controlling infection in the coronary artery. The expression and function of SP-A in the coronary artery has not yet been explored in depth, but it was seen that SP-A mRNA was detectable in human coronary artery smooth muscle cells and that the administration of SP-A also inhibited the LPS-induced release of IL-8, thus SP-A is likely to play a similar role to SP-D here [63].

\section{The Skin}

SP-A and SP-D expression has been detected in the skin using both RT-PCR as well as immunohistochemistry to further localise their expression in different layers of the skin. Both proteins were found in the epidermis, with SP-A detected in the stratum corneum and stratum granulosum and SP-D detected in all epidermal layers as well as the dermis [64]. Interestingly, it is within these outer skin layers that contact with pathogens often occurs, and SP-A and SP-D may be contributing to the innate defences already located here. It has been noted that SP-A and SP-D may also play a role in certain inflammatory skin diseases. Skin biopsy samples from individuals with psoriasis, atopic dermatitis, lichen planus or Behçet's disease were observed to have higher levels of SP-A and SP-D present compared to normal skin samples [65]. The strong expression of SP-A and SP-D in these inflammatory pathologies further highlights the role of SP-A and SP-D in inflammation.

\section{Conclusion}

It is now known that expression of the immune SPs is not exclusive to the lungs. Their expression in other regions including the reproductive tract, urinary tract, and GIT and their interaction with various pathogens (ta- 
Table 1. Relationships between surfactant proteins A and D and different pathogens in non-pulmonary sites

\begin{tabular}{|c|c|c|c|c|c|}
\hline Alternaria tenuis & Nasal tissue & $?$ & + & $\begin{array}{l}\text { Infection with } A \text {. tenuis is associated with } \\
\text { increased SP-D expression during chronic } \\
\text { rhinosinusitis }\end{array}$ & Ooi et al. [61], 2007 \\
\hline Aspergillus fumigatus & Nasal tissue & $?$ & + & $\begin{array}{l}\text { Infection with } A \text {. fumigatus is associated } \\
\text { with increased SP-D expression during } \\
\text { chronic rhinosinusitis }\end{array}$ & Ooi et al. [61], 2007 \\
\hline Chlamydia muridarum & $\begin{array}{l}\text { Murine } \\
\text { reproductive tract }\end{array}$ & $?$ & + & $\begin{array}{l}\text { Infection with C. muridarum increases } \\
\text { SP-D expression in the cervix }\end{array}$ & $\begin{array}{l}\text { Oberley et al. [25], } \\
2007\end{array}$ \\
\hline Chlamydia pneumoniae & Coronary artery & $?$ & + & $\begin{array}{l}\text { SP-D reduces the amount of viable } C \text {. } \\
\text { pneumoniae inclusions }\end{array}$ & $\begin{array}{l}\text { Snyder et al. [63], } \\
2008\end{array}$ \\
\hline Chlamydia trachomatis & $\begin{array}{l}\text { Female } \\
\text { reproductive tract }\end{array}$ & + & + & $\begin{array}{l}\text { SP-D prevents HeLa cell infection by } C \text {. } \\
\text { trachomatis. SP-A and SP-D enhance uptake } \\
\text { of } C \text {. trachomatis by THP-1 macrophages }\end{array}$ & $\begin{array}{l}\text { Oberley et al. [26], } \\
2004\end{array}$ \\
\hline $\begin{array}{l}\text { Escherichia coli } \\
\text { (various strains) }\end{array}$ & GIT & $?$ & + & $\begin{array}{l}\text { SP-D aggregates } E \text {. coli, enhancing its uptake } \\
\text { by intestinal epithelial cells }\end{array}$ & $\begin{array}{l}\text { Hogenkamp et al. } \\
{[43], 2007}\end{array}$ \\
\hline Klebsiella pneumoniae & Ear & + & $?$ & $\begin{array}{l}\text { Infection with } K \text {. pneumoniae-derived LPS } \\
\text { increases SP-A expression in the middle ear }\end{array}$ & Li et al. [57], 2015 \\
\hline Pseudomonas aeruginosa & Eye & $?$ & + & $\begin{array}{l}\text { SP-D knockout mice do not clear infection } \\
\text { as efficiently }\end{array}$ & $\begin{array}{l}\text { Mun et al. [52], } \\
2009\end{array}$ \\
\hline $\begin{array}{l}\text { Salmonella enteritidis, } \\
\text { Salmonella typhimurium, } \\
\text { group B Salmonella }\end{array}$ & GIT & $?$ & + & $\begin{array}{l}\text { SP-D aggregates Salmonella, enhancing its } \\
\text { uptake by intestinal epithelial cells }\end{array}$ & $\begin{array}{l}\text { Hogenkamp et al. } \\
{[43], 2007}\end{array}$ \\
\hline Herpes simplex virus 1 & Mouth & + & $?$ & $\begin{array}{l}\text { SP-A is shown to interact with HSV-1, but } \\
\text { the consequences of this are unknown }\end{array}$ & $\begin{array}{l}\text { van Iwaarden et al. } \\
\text { [67], } 1992\end{array}$ \\
\hline $\begin{array}{l}\text { Human immunodeficiency } \\
\text { virus }\end{array}$ & $\begin{array}{l}\text { Reproductive } \\
\text { tract }\end{array}$ & + & + & $\begin{array}{l}\text { SP-A and SP-D inhibit HIV infectivity of } \\
\text { CD } 4 \text { cells but enhance uptake by dendritic } \\
\text { cells }\end{array}$ & $\begin{array}{l}\text { Gaiha et al. [27], } \\
\text { 2008; Madsen et al. } \\
\text { [28], } 2013\end{array}$ \\
\hline Aspergillus fumigatus & Eye & $?$ & + & $\begin{array}{l}\text { Infection with A. fumigatus spores increases } \\
\text { SP-D expression in human corneal epithelial } \\
\text { cells }\end{array}$ & $\begin{array}{l}\text { Che et al. [54], } \\
2012\end{array}$ \\
\hline
\end{tabular}

+ indicates a relationship between pathogen and protein; ? indicates a relationship is unknown. Only non-pulmonary interactions are stated here. 
ble 1) suggest that they play a more general role in innate immunity, with SP-D generally displaying more widespread activities. It may therefore be possible to develop SPs as broad-spectrum alternative means for the prevention and/or novel therapeutic approaches for the treatment of common infections, which may be especially beneficial for individuals who are immunocompromised.

\section{Acknowledgements}

This work was supported by funding provided from the University of Cape Town, the Sir Halley Stewart Trust, the Poliomyelitis Research Foundation, the Cancer Association of South Africa and the National Research Foundation of South Africa.

\section{Disclosure Statement}

The authors state no conflict of interest.

\section{References}

1 Pattle RE: Properties, function and origin of the alveolar lining layer. Nature 1955;175: 1125-1126.

2 Wright JR: Immunoregulatory functions of surfactant proteins. Nat Rev Immunol 2005;5: 58-68.

3 Kishore U, Greenhough TJ, Waters P, Shrive AK, Ghai R, Kamran MF, Bernal AL, Reid KB, Madan T, Chakraborty T: Surfactant proteins SP-A and SP-D: structure, function and receptors. Mol Immunol 2006;43:1293-1315.

4 Jäkel A, Qaseem AS, Kishore U, Sim RB: Ligands and receptors of lung surfactant proteins SP-A and SP-D. Front Biosci (Landmark Ed) 2013;18:1129-1140.

5 Head JF, Mealy TR, McCormack FX, Seaton BA: Crystal structure of trimeric carbohydrate recognition and neck domains of surfactant protein A. J Biol Chem 2003;278: 43254-43260.

6 Zhang P, McAlinden A, Li S, Schumacher T, Wang H, Hu S, Sandell L, Crouch E: The amino-terminal heptad repeats of the coiled-coil neck domain of pulmonary surfactant protein $\mathrm{D}$ are necessary for the assembly of trimeric subunits and dodecamers. J Biol Chem 2001; 276:19862-19870.

7 Hartshorn KL, White MR, Shepherd V, Reid $\mathrm{K}$, Jensenius JC, Crouch EC: Mechanisms of anti-influenza activity of surfactant proteins $\mathrm{A}$ and D: comparison with serum collectins. Am J Physiol 1997;273:L1156-L1166.

8 LeVine AM, Elliott J, Whitsett JA, Srikiatkhachorn A, Crouch E, DeSilva N, Korfhagen T: Surfactant protein-D enhances phagocytosis and pulmonary clearance of respiratory syncytial virus. Am J Respir Cell Mol Biol 2004; 31:193-199.

9 LeVine AM, Whitsett JA, Gwozdz JA, Richardson TR, Fisher JH, Burhans MS, Korfhagen TR: Distinct effects of surfactant protein $\mathrm{A}$ or $\mathrm{D}$ deficiency during bacterial infection on the lung. J Immunol (Baltimore, Md: 1950) 2000;165:3934-3940.

10 LeVine AM, Whitsett JA, Hartshorn KL, Crouch EC, Korfhagen TR: Surfactant protein $\mathrm{D}$ enhances clearance of influenza A virus from the lung in vivo. J Immunol (Baltimore, Md: 1950) 2001;167:5868-5873.

11 Ferguson JS, Martin JL, Azad AK, McCarthy TR, Kang PB, Voelker DR, Crouch EC, Schlesinger LS: Surfactant protein D increases fusion of Mycobacterium tuberculosis-containing phagosomes with lysosomes in human macrophages. Infect Immun 2006;74: 7005-7009.

12 Gaynor CD, McCormack FX, Voelker DR, McGowan SE, Schlesinger LS: Pulmonary surfactant protein A mediates enhanced phagocytosis of Mycobacterium tuberculosis by a direct interaction with human macrophages. J Immunol (Baltimore, Md: 1950) 1995; 155:5343-5351.

13 Ghildyal R, Hartley C, Varrasso A, Meanger J, Voelker DR, Anders EM, Mills J: Surfactant protein A binds to the fusion glycoprotein of respiratory syncytial virus and neutralizes virion infectivity. J Infect Dis 1999;180:20092013.

14 Madan T, Eggleton P, Kishore U, Strong P, Aggrawal SS, Sarma PU, Reid KB: Binding of pulmonary surfactant proteins $\mathrm{A}$ and $\mathrm{D}$ to $A s$ pergillus fumigatus conidia enhances phagocytosis and killing by human neutrophils and alveolar macrophages. Infect Immun 1997;65: 3171-3179.

15 Thawer S, Auret J, Schnoeller C, Chetty A, Smith K, Darby M, Roberts L, Mackay RM, Whitwell HJ, Timms JF, Madsen J, Selkirk ME, Brombacher F, Clark HW, Horsnell WG: Surfactant protein-D is essential for immunity to helminth infection. PLoS Pathogens 2016;12:e1005461.

16 Jäkel A, Clark H, Reid KB, Sim RB: The human lung surfactant proteins A (SP-A) and D (SP-D) interact with apoptotic target cells by different binding mechanisms. Immunobiology 2010;215:551-558.

17 Gardai SJ, Xiao YQ, Dickinson M, Nick JA, Voelker DR, Greene KE, Henson PM: By binding SIRPalpha or calreticulin/CD91, lung collectins act as dual function surveillance molecules to suppress or enhance inflammation. Cell 2003;115:13-23.
18 Botas C, Poulain F, Akiyama J, Brown C, Allen L, Goerke J, Clements J, Carlson E, Gillespie AM, Epstein C, Hawgood S: Altered surfactant homeostasis and alveolar type II cell morphology in mice lacking surfactant protein D. Proc Natl Acad Sci USA 1998;95: 11869-11874.

19 Korfhagen TR, Bruno MD, Ross GF, Huelsman KM, Ikegami M, Jobe AH, Wert SE, Stripp BR, Morris RE, Glasser SW, Bachurski CJ, Iwamoto HS, Whitsett JA: Altered surfactant function and structure in SP-A gene targeted mice. Proc Natl Acad Sci USA 1996;93: 9594-9599.

20 Mackay RM, Grainge CL, Lau LC, Barber C, Clark HW, Howarth PH: Airway surfactant protein $\mathrm{D}$ deficiency in adults with severe asthma. Chest 2016;149:1165-1172.

21 Garcia-Verdugo I, Tanfin Z, Dallot E, Leroy MJ, Breuiller-Fouche M: Surfactant protein A signaling pathways in human uterine smooth muscle cells. Biol Reprod 2008;79:348-355.

22 MacNeill C, Umstead TM, Phelps DS, Lin Z, Floros J, Shearer DA, Weisz J: Surfactant protein $\mathrm{A}$, an innate immune factor, is expressed in the vaginal mucosa and is present in vaginal lavage fluid. Immunology 2004;111:91-99.

23 Leth-Larsen R, Floridon C, Nielsen O, Holmskov U: Surfactant protein D in the female genital tract. Mol Hum Reprod 2004;10:149154.

24 MacNeill C, de Guzman G, Sousa GE, Umstead TM, Phelps DS, Floros J, Ahn K, Weisz $\mathrm{J}$ : Cyclic changes in the level of the innate immune molecule, surfactant protein- $\mathrm{A}$, and cytokines in vaginal fluid. Am J Reprod Immunol (New York, NY: 1989) 2012;68:244-250.

25 Oberley RE, Goss KL, Hoffmann DS, Ault KA, Neff TL, Ramsey KH, Snyder JM: Regulation of surfactant protein $\mathrm{D}$ in the mouse female reproductive tract in vivo. Mol Hum Reprod 2007;13:863-868.

26 Oberley RE, Goss KL, Ault KA, Crouch EC, Snyder JM: Surfactant protein D is present in the human female reproductive tract and inhibits Chlamydia trachomatis infection. Mol Hum Reprod 2004;10:861-870. 
27 Gaiha GD, Dong T, Palaniyar N, Mitchell DA, Reid KB, Clark HW: Surfactant protein A binds to HIV and inhibits direct infection of CD4+ cells, but enhances dendritic cell-mediated viral transfer. J Immunol (Baltimore, Md: 1950) 2008;181:601-609.

28 Madsen J, Gaiha GD, Palaniyar N, Dong T, Mitchell DA, Clark HW: Surfactant protein D modulates HIV infection of both T-cells and dendritic cells. PLoS One 2013;8:e59047.

29 Madhukaran SP, Koippallil Gopalakrishnan AR, Pandit H, Marri ED, Kouser L, Jamil K, Alhamlan FS, Kishore U, Madan T: Expression of surfactant proteins SP-A and SP-D in murine decidua and immunomodulatory effects on decidual macrophages. Immunobiology 2016;221:377-386.

30 Miyamura K, Malhotra R, Hoppe HJ, Reid KB, Phizackerley PJ, Macpherson P, Lopez Bernal A: Surfactant proteins A (SP-A) and D (SP-D): levels in human amniotic fluid and localization in the fetal membranes. Bioch Biophys Acta 1994;1210:303-307.

31 Madhukaran SP, Kishore U, Jamil K, Choolani $\mathrm{M}, \mathrm{Lu}$ J: Decidual expression and localization of human surfactant protein SP-A and SP-D, and complement protein C1q. Mol Immunol 2015;66:197-207.

32 Lee DC, Romero R, Kim CJ, Chaiworapongsa T, Tarca AL, Lee J, Suh YL, Mazaki-Tovi S, Vaisbuch E, Mittal P, Draghici S, Erez O, Kusanovic JP, Hassan SS, Kim JS: Surfactant protein- $\mathrm{A}$ as an anti-inflammatory component in the amnion: implications for human pregnancy. J Immunol (Baltimore, Md: 1950) 2010;184:6479-6491.

33 Han YM, Romero R, Kim YM, Kim JS, Richani K, Friel LA, Kusanovic JP, Jeanty C, Vitale S, Nien JK, Espinoza J, Kim CJ: Surfactant protein-A mRNA expression by human fetal membranes is increased in histological chorioamnionitis but not in spontaneous labour at term. J Pathol 2007;211:489-496.

34 Karjalainen MK, Huusko JM, Tuohimaa A, Luukkonen A, Haataja R, Hallman M: A study of collectin genes in spontaneous preterm birth reveals an association with a common surfactant protein D gene polymorphism. Pediatr Res 2012;71:93-99.

35 Condon JC, Jeyasuria P, Faust JM, Mendelson CR: Surfactant protein secreted by the maturing mouse fetal lung acts as a hormone that signals the initiation of parturition. Proc Natl Acad Sci USA 2004;101:4978-4983.

36 Agrawal V, Smart K, Jilling T, Hirsch E: Surfactant protein (SP)-A suppresses preterm delivery and inflammation via TLR2. PLoS One 2013;8:e63990.

37 Hu F, Ding G, Zhang Z, Gatto LA, Hawgood S, Poulain FR, Cooney RN, Wang G: Innate immunity of surfactant proteins $\mathrm{A}$ and $\mathrm{D}$ in urinary tract infection with uropathogenic Escherichia coli. Innate Immun 2016;22:9-20.
38 Madsen J, Kliem A, Tornoe I, Skjodt K, Koch C, Holmskov U: Localization of lung surfactant protein $\mathrm{D}$ on mucosal surfaces in human tissues. J Immunol (Baltimore, Md: 1950) 2000; 164:5866-5870.

39 Kurimura Y, Nishitani C, Ariki S, Saito A, Hasegawa Y, Takahashi M, Hashimoto J, Takahashi S, Tsukamoto T, Kuroki Y: Surfactant protein $\mathrm{D}$ inhibits adherence of uropathogenic Escherichia coli to the bladder epithelial cells and the bacterium-induced cytotoxicity: a possible function in urinary tract. J Biol Chem 2012;287:39578-39588.

$40 \mathrm{Hu}$ F, Liang W, Ren Z, Wang G, Ding G: Surfactant protein $\mathrm{D}$ inhibits lipopolysaccharideinduced monocyte chemoattractant protein-1 expression in human renal tubular epithelial cells: implication for tubulointerstitial fibrosis. Clin Exp Immunol 2012;167:514522.

41 Liu J, Hu F, Liang W, Wang G, Singhal PC, Ding G: Polymorphisms in the surfactant protein A gene are associated with the susceptibility to recurrent urinary tract infection in Chinese women. Tohoku J Exp Med 2010; 221:35-42.

42 Lin Z, deMello D, Phelps DS, Koltun WA, Page M, Floros J: Both human SP-A1 and Sp$\mathrm{A} 2$ genes are expressed in small and large intestine. Pediatr Pathol Mol Med 2001;20:367386.

43 Hogenkamp A, Herias MV, Tooten PC, Veldhuizen EJ, Haagsman HP: Effects of surfactant protein $\mathrm{D}$ on growth, adhesion and epithelial invasion of intestinal Gram-negative bacteria. Mol Immunol 2007;44:3517-3527.

44 Luo JM, Liu ZQ, Eugene CY: Overexpression of pulmonary surfactant protein A like molecules in inflammatory bowel disease tissues. Zhong Nan Da Xue Xue Bao Yi Xue Ban 2008; 33:979-986.

45 Lin Z, John G, Hegarty JP, Berg A, Yu W, Wang Y, Kelly AA, Peterson BZ, Poritz LS, Floros J, Koltun WA: Genetic variants and monoallelic expression of surfactant protein$\mathrm{D}$ in inflammatory bowel disease. Ann Hum Genet 2011;75:559-568.

46 Saka R, Wakimoto T, Nishiumi F, Sasaki T, Nose S, Fukuzawa M, Oue T, Yanagihara I, Okuyama H: Surfactant protein-D attenuates the lipopolysaccharide-induced inflammation in human intestinal cells overexpressing Toll-like receptor 4. Pediatr Surg Int 2016;32: 59-63.

47 Quintanilla HD, Liu Y, Fatheree NY, Atkins CL, Hashmi SS, Floros J, McCormack FX, Rhoads JM, Alcorn JL: Oral administration of surfactant protein-A reduces pathology in an experimental model of necrotizing enterocolitis. J Pediatr Gastroenterol Nutr 2015;60: 613-620.

48 Bräuer L, Moschter S, Beileke S, Jager K, Garreis F, Paulsen FP: Human parotid and submandibular glands express and secrete surfactant proteins A, B, C and D. Histochem Cell Biol 2009;132:331-338.
49 Schicht M, Stengl C, Sel S, Heinemann F, Gotz W, Petschelt A, Pelka M, Scholz M, Rausch F, Paulsen F, Brauer L: The distribution of human surfactant proteins within the oral cavity and their role during infectious diseases of the gingiva. Ann Anat 2015;199:92-97.

50 Lee HM, Park IH, Woo JS, Chae SW, Kang HJ, Hwang SJ: Up-regulation of surfactant protein A in chronic sialadenitis. Arch Otolaryngol Head Neck Surg 2005;131:1108-1111.

51 Bräuer L, Kindler C, Jager K, Sel S, Nolle B, Pleyer U, Ochs M, Paulsen FP: Detection of surfactant proteins $\mathrm{A}$ and $\mathrm{D}$ in human tear fluid and the human lacrimal system. Invest Ophthalmol Vis Sci 2007;48:3945-3953.

52 Mun JJ, Tam C, Kowbel D, Hawgood S, Barnett MJ, Evans DJ, Fleiszig SM: Clearance of Pseudomonas aeruginosa from a healthy ocular surface involves surfactant protein $\mathrm{D}$ and is compromised by bacterial elastase in a murine null-infection model. Infect Immun 2009;77:2392-2398.

53 Zhang Z, Abdel-Razek O, Hawgood S, Wang G: Protective role of surfactant protein D in ocular Staphylococcus aureus infection. PLoS One 2015;10:e0138597.

54 Che CY, Jia WY, Xu Q, Li N, Hu LT, Jiang N, Lin J, Wang Q, Zhao GQ: The roles of surfactant protein D during Aspergillus fumigatus infection in human corneal epithelial cells. Int J Ophthalmol 2012;5:13-17.

55 Ni M, Tam C, Verma A, Ramphal R, Hawgood S, Evans DJ, Fleiszig SM: Expression of surfactant protein D in human corneal epithelial cells is upregulated by Pseudomonas aeruginosa. FEMS Immunol Med Microbiol 2008;54:177-184.

56 Paananen R, Sormunen R, Glumoff V, van Eijk M, Hallman M: Surfactant proteins A and $\mathrm{D}$ in eustachian tube epithelium. Am J Physiol Lung Cell Mol Physiol 2001;281:L660L667.

57 Li L, Guo X, Olszewski E, Fan Z, Ai Y, Han Y, $\mathrm{Xu} \mathrm{L,} \mathrm{Li} \mathrm{J,} \mathrm{Wang} \mathrm{H:} \mathrm{Expression} \mathrm{of} \mathrm{surfactant}$ protein-A during LPS-induced otitis media with effusion in mice. Otolaryngol Head Neck Surg 2015;153:433-439.

58 Kim JK, Kim SS, Rha KW, Kim CH, Cho JH, Lee CH, Lee JG, Yoon JH: Expression and localization of surfactant proteins in human nasal epithelium. Am J Physiol Lung Cell Mol Physiol 2007;292:L879-L884.

59 Uhliarova B, Kopincova J, Adamkov M, Svec M, Calkovska A: Surfactant proteins A and D are related to severity of the disease, pathogenic bacteria and comorbidity in patients with chronic rhinosinusitis with and without nasal polyps. Clin Otolaryngol 2016;41:249258

60 Woodworth BA, Neal JG, Newton D, Joseph K, Kaplan AP, Baatz JE, Schlosser RJ: Surfactant protein $\mathrm{A}$ and $\mathrm{D}$ in human sinus mucosa: a preliminary report. ORL J Otorhinolaryngol Relat Spec 2007;69:57-60. 
61 Ooi EH, Wormald PJ, Carney AS, James CL, Tan LW: Surfactant protein D expression in chronic rhinosinusitis patients and immune responses in vitro to Aspergillus and Alternar$i a$ in a nasal explant model. Laryngoscope 2007;117:51-57.

62 Schob S, Schicht M, Sel S, Stiller D, Kekule AS, Paulsen F, Maronde E, Bräuer L: The detection of surfactant proteins $A, B, C$ and $D$ in the human brain and their regulation in cerebral infarction, autoimmune conditions and infections of the CNS. PLoS One 2013;8:e74412.
63 Snyder GD, Oberley-Deegan RE, Goss KL, Romig-Martin SA, Stoll LL, Snyder JM, Weintraub NL: Surfactant protein D is expressed and modulates inflammatory responses in human coronary artery smooth muscle cells. Am J Physiol Heart Circ Physiol 2008;294:H2053-H2059.

64 Mo YK, Kankavi O, Masci PP, Mellick GD, Whitehouse MW, Boyle GM, Parsons PG, Roberts MS, Cross SE: Surfactant protein expression in human skin: evidence and implications. J Invest Dermatol 2007;127:381-386.
65 Akman A, Kankavi O, Ciftcioglu MA, Alpsoy E: Surfactant proteins in inflammatory skin diseases: controlled study. Arch Dermatol Res 2008;300:353-356.

66 Okogbule-Wonodi AC, Chesko KL, Famuyide ME, Viscardi RM: Surfactant protein-A enhances ureaplasmacidal activity in vitro. Innate Immun 2011;17:145-151.

67 van Iwaarden JF, van Strijp JA, Visser H, Haagsman HP, Verhoef J, van Golde LM: Binding of surfactant protein A (SP-A) to herpes simplex virus type 1 -infected cells is mediated by the carbohydrate moiety of SP-A. J Biol Chem 1992;267:25039-25043. 